\title{
Difficult Horn Passages
}

Author(s): E. W. Whinfield

Source: The Musical Times and Singing Class Circular, Vol. 36, No. 625 (Mar. 1, 1895), p. 190 Published by: Musical Times Publications Ltd.

Stable URL: http://www.jstor.org/stable/3364677

Accessed: 23-06-2016 15:10 UTC

Your use of the JSTOR archive indicates your acceptance of the Terms \& Conditions of Use, available at

http://about.jstor.org/terms

JSTOR is a not-for-profit service that helps scholars, researchers, and students discover, use, and build upon a wide range of content in a trusted digital archive. We use information technology and tools to increase productivity and facilitate new forms of scholarship. For more information about JSTOR, please contact support@jstor.org.

Musical Times Publications Ltd. is collaborating with JSTOR to digitize, preserve and extend access to The Musical Times and Singing Class Circular 
imparting to more than a few of our "musical" pupils a firm, even touch or rapid technique. And just as long as this is the case, so long will the mental and technical difficulties be confounded, the musical periodicals be full of fruitless discussions on "touch," and the present anomalies in teaching the pianoforte-each professor adopting separate principles-continue unaltered. Yours, \&c.,

Macdonald Smith.

\section{THE NEW CRITICISM.}

TO THE EDITOR OF " THE MUSICAL TIMES."

Sir,-May I be allowed to call attention, in your columns, to a specimen of the New Criticism, as practised by a prominent evening London newspaper?

Some three weeks ago an important work, new to London, was produced at the Albert Hall. On the day previous to the performance, the paper in question published a preliminary article on the work, from which we extract one typical sentence : " $\mathrm{He}$ (the composer) avoids anything like clearness of melody and easy symmetry of thought, as he would avoid the devil himself." Then, after some further remarks, the critic concludes, "We would not prejudice Thursday night's performance."

For sheer effrontery I think this would be hard to beat, even amongst the files of the newspaper in question.

Faithfully yours,

G MINOR.

\section{DIFFICULT HORN PASSAGES.}

TO THE EDITOR OF "THE MUSICAL TIMES."

SiR,- It may interest some of your readers (as well as the writer) of the notice of Vivier (in the February number of The Musical Times) to know that not only did Vivie really produce a chord of three, or even four, notes simultaneously, but that he was neither the first nor the only player who has been able to do so.

In Carl M. von Weber's Concertino for horn (written in I8I5) the following passage occurs at the end of the Cadenza (after the Recitative)-
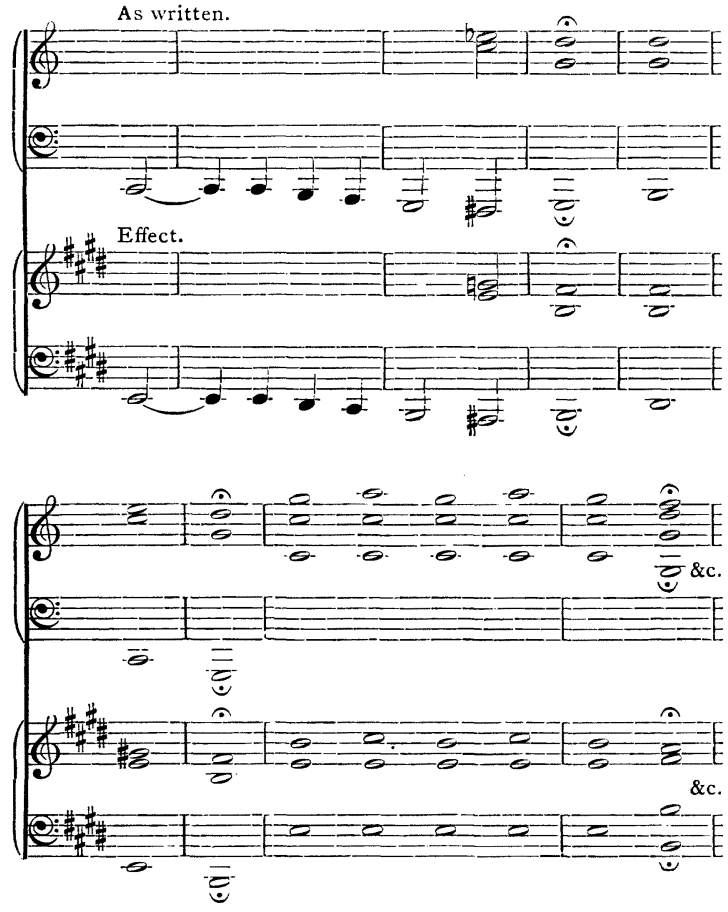

Jähns, in his Thematic Catalogue of Weber's Compositions (p. 20I), has a note, of which I translate a portion, to the following effect :
"In the final Cadenza an uncommon effect is to be noticed; a passage of nine bars for the horn alone, in three and four-part harmony. So that Weber, in 1815 already indicated an effect, which, after having been entirely forgotten, was revived by the celebrated Vivier about thirty-five years later, and created an extraordinary sensation.'

He goes on to explain-not, I think, quite completelyhow the effect is produced.

I can testify to the possibility of the effect, as I have often heard it produced, more or less completely, by a moderately skilful amateur.--I am, \&c.,

Severn Grange, Worcester.

E. W. WhiNFIELD.

P.S.-The same Concertino contains, in the final Polonaise, some rather surprising passages, such as-

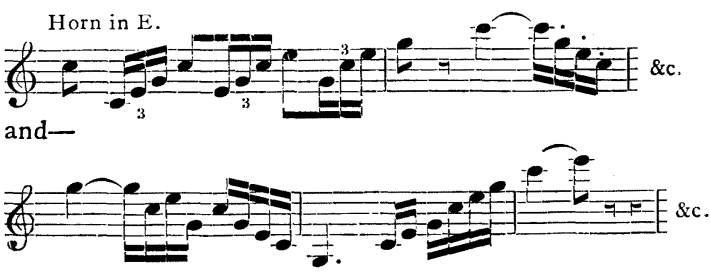

TO CORRESPONDENTS

** Notices of concerts, of which programmes must invariably be sent and other information supplied by our friends in the country, mus be forwarded as early as possible after the occurrence; otherwis they cannot be inserted.

Our correspondents will oblige by writing all names as clearly as possible, as we cannot be responsible for any mistakes that may occur.

Correspondents are informed that their names and addresses mus: accompany all communications.

We cannot undertake to return offered contributions; the authors therefore, will do well to retain copies.

Notice is sent to all subscribers whose payment (in advance) is exhausted. The paper will be discontinued where the Subscription is not renewed. We again remind those who are disappointed in obtainin back numbers that, although the music is always kept in stock, only a sufficient quantity of the rest of the paper is printed to supply the current sale.

F. W. WEIRTER (Geelong).-Thanks; but the subject is now too stale in Great Britain.

J. D. Horwood,-César Franck died at Paris from the effects of an accident, November 8,1890 .

\section{BRIEF SUMMARY OF COUNTRY NEWS}

We do not hold ourselves responsible for any opinions expressed in this ummary, as all the notices are either collated from the local papers or supplied to us by correspondents.

Basingstoke.-On the IIth ult. the Harmonic Society gave excellent performances of Beethoven's " Mount of Olives" and Cowen's "Sleeping Beauty." The soloists were Miss Kate Drew, Miss Mary Reeve, Mr. Charles Butler, and Mr. Giffard Wells. Mr. J. S. Liddle led the band and $\mathrm{Mr}$. W. H. Liddle conducted.

BEDFORD.-Mdlle. de Nolhac gave a Matinée musicale at the Town Hall, on the 2nd ult. Mdlle. de Nolhac, whose efforts were heartily appreciated, was assisted by $\mathrm{Mr}$. Templer Saxe, Miss M. Chetham (solo violin), and Miss Ethel Herbert (reciter). Dr. H. A. Harding acted as accompanist.

BlackBURN.-A most successful choral contest took place on the gth ult. There were five entries for the competition, which was open to all musical societies and choirs of thirty-five voices and under. Mr. R. H. Wilson was the adjudicator, and gave the first prize to Accrington Wesley Choir, the second to Leeds Vocal Union, and the third to the Ramsbottom Presbyterian Choir. Very large audiences were present both afternoon and evening.

Brighouse. - The Choral Society, conducted by Mr. J. H. Pearson, gave an attractive miscellaneous Concert on the $5^{\text {th }}$ ult., in the Town Hall. The choir was heard in Schubert's "Forth to the Meadows," Mendelssohn's "Hunting Song" (Op. 59), and some choruses; and Madame Thomas, associated with Messrs. Tomlinson, 